\title{
THE MOST ABUNDANCE AND THE VERY RARE SPECIES IN THE DEEP SEA FISH COMMUNITY IN THE WESTERN SUMATERA, EASTERN INDIAN OCEAN
}

\author{
Badrudin"), Duto Nugroho"), and Ali Suman') \\ 1) Research Institute for Marine Fisheries, Muara Baru-Jakarta \\ 2) Research Center for Capture Fisheries, Ancol-Jakarta
}

Received December 22-2006; Received in revised February 19-2007; Accepted March 6-2007

\begin{abstract}
Variation in species abundance provides one of the striking phenomena observed in ecological communities. This variation has led ecologists to pose central questions pertaining to the nature of communities. Most of the deep sea regions provide the most widely habitat, but until recently information on its community is very little. Data analyzed were parts of the results of exploratory trawling using RN Baruna Jaya IV, carried out in June and July 2005. Exploratory fishing covered the depth range of 250 to $1,000 \mathrm{~m}$. Catch data analysis were grouped into three depth fishing zones; the $<500 \mathrm{~m}, 500$ to $750 \mathrm{~m}$, and 751 to $1,000 \mathrm{~m}$. From the Richness index, it was found that within the depth range of 250 to $1,000 \mathrm{~m}$ the number of species seems to be increased toward the deeper waters. The six species of importance in term of number of individual fish, were the lantern fish myctophid, Diaphus sp.1, the rat tail macrourid, Caelorinchus divergens, the neoscopelid, Neoscopelus macrolepidotus, the spinyfin, Diretmoides pauciradiatus, the alepocephalid, Bajacalifornia erimorensis and the trachichthyd Hoplostetus crassispinus. Other endemic fish species consisted of two main groups, the rare and the very rare species. The very rare species in each depth zone in the waters around Enggano was between 9 to 35 species, in the western part of Bengkulu was 14 to 20 species, in the area around Simeuleu was 9 to 33 species, and in the western part of Banda Aceh was 11 to 24 species. Based on the catch composition data in each area from the SE of Enggano to the western part of Banda Aceh, it is likely that there are some differences in the deep sea fish community between the southern and the northern waters of the imaginary line of the equator. These differences that need further research are probably related with the movement pattern of the water current occurring in the deep-sea floor which are likely affect the bottom substrate and ultimately affect the fish community inhabited this area.
\end{abstract}

KEYWORDS: deep sea fish community, the most abundance and the very rare species, Western Sumatera waters, Eastern Indian Ocean

\section{INTRODUCTION}

With respect to the amount of light that is present, the marine region are roughly divided vertically into three zones; the eupothic, the dispothic and the apothic zones (Sverdrup et al., 1946). The euphotic zone which is abundantly supplied with light sufficient for photosynthetic of plant in Indonesian waters is considered up to $100 \mathrm{~m}$ depth (Sugiarto \& Birowo, 1975). The disphotic zone which is only dimly lighted extend to about $200 \mathrm{~m}$ or more, while the aphotic zone, the lightless region below the disphotic zone where the environmental conditions are in perpetual darkness. Deep sea environment which includes the disphotic and the aphotic zones provide the most widely habitat with little information on its community. The area of shallow marine waters bordering with continents and islands is only about $10 \%$ from the total area of the ocean. Ninety percent of the ocean volume consisted of deep waters which are dark and cold, and information on the aspects of life is still very rare (Nybakken, 1986). The main environmental factors affecting deep sea region are light, hydrostatics pressure, salinity, temperature, oxigen, and food supply.
The availability of deep sea fish data provides additional information regarding biodiversity of fish resources community. It was reported that within the marine waters there were about 12,000 fish species, of which about 2,000 species have been identified and grouped as the deep-sea dwelling species (Marshall, 1979). In the background of species abundance relations, Ludwig \& Reynolds (1988), explain that variation in species abundance provide one of the striking phenomena observed in ecological communities. This variation has led ecologists to pose central questions pertaining to the nature of communities. How many species are there and what are their relative abundances? How many are rare and how many are common?

This paper describes some aspects of deep sea fish communities which include species richness, the most abundance species, the abundance, the less abundance, the rare, and the very rare species. Information on these aspects can be used as a baseline data for further research and assessment activities carried out in both similar marine waters or other areas with similar waters characteristics and similar biophysical

Corresponding author:

Komplek Pelabuhan Perikanan Samudera JI. Muara Baru Ujung-Jakarta 14440, E-mail: kanlutmb@indosat.net.id 
conditions. Results of the anaylisis provide a complementary information for the results of the exploratory trawling carried out using the RN Baruna Jaya IV reported by the Overseas Fishery Cooperation Foundation and the Agency for Marine and Fisheries Research, Ministry of Marine Affairs and Fisheries, Indonesia (Anonymous, 2006).

\section{MATERIALS AND METHODS}

Catch data analyzed were parts of the results of exploratory trawling using the R/V Baruna Jaya IV (Anonymous, 2006). The catches from each of a total of 50 trawl fishing stations were sorted to either species, genus, and family. For the purpose of analysis, the catches of each species were counted $(\mathrm{N})$. Exploratory fishing covered the depth range of 250 to $1,000 \mathrm{~m}$, while data analysis in this paper was limited only to the exploratory results carried out in the western Sumatera as a complementary information reported by Badrudin et al. (2006). These data were grouped into three depth fishing zones; the $<500 \mathrm{~m}, 500$ to $750 \mathrm{~m}, 751$ to 1,000 $\mathrm{m}$. Calculation of Menhinick Richness index (R) following the procedure explained in Ludwig \& Reynold (1988). Identification of the most abundance, abundance, and less abundance species were carried out arbitrarily in accordance with the number of fish caught relative to the total catch. The rare species was identified as the number of fish found in 2 to 3 specimens while the very rare species was determined as only one specimen found in the total catch of each depth range. Fish identifications were done following Nakabo (2002).

\section{RESULTS AND DISCUSSIONS}

\section{Fishing Areas and Trawling Stations}

The fishing areas have been selected based on the trawlable grounds, which were considered as relatively flat bottom surface. Following Badrudin et al. (2006), the first fishing area was located about $60 \mathrm{~nm}$ distant from Enggano Island to the SE direction. The survey area extends from NW to SE like a belt shape and is bordered with territorial line. Ten hauls of trawling in this area were completed (Table 1). The second fishing area was located in the western part of Bengkulu. During this cruise there were only four tows allocated in proportion to the size of the area. In the third fishing area which was located in the northwestern part of Simeuleu island, 25 trawling stations have been carried out. In the fourth area which was located in the western part of Banda Aceh, 11 trawl fishing stations were carried out and completed.

Table 1.

The survey areas and number of trawl hauls in each depth strata

\begin{tabular}{lcccc}
\hline \multirow{2}{*}{ Area/depth range } & \multicolumn{4}{c}{ Number of trawl fishing stations } \\
\cline { 2 - 5 } & $<\mathbf{5 0 0}$ & $\mathbf{5 0 0 - 7 5 0 m}$ & $\mathbf{7 5 1 - 1 , 0 0 0 m}$ & Total \\
\hline Enggano & 3 & 3 & 4 & 10 \\
Bengkulu & - & 2 & 2 & 4 \\
Simeuleu & 1 & 12 & 12 & 25 \\
Banda Aceh & 3 & 4 & 4 & 11 \\
Total & $\mathbf{7}$ & $\mathbf{2 1}$ & $\mathbf{2 2}$ & $\mathbf{5 0}$ \\
\hline
\end{tabular}

\section{The Waters of the SE part of Enggano}

It is likely that within the depth range of 250 to 1,000 $m$ in this waters, the number of species seems to be increased toward the deeper waters. This is reflected in the Menhinick Richness index, where the index in the depth zone 751 to $1,000 \mathrm{~m}$ is $83.9 \%$ higher than the index in the depth zone 500 to $750 \mathrm{~m}$. Similary the index in the later depth zone is $80.6 \%$ higher than the index in depth zone $<500 \mathrm{~m}$ (Table 2).

It is also appeared that the number of the most abundance species in each of the three depth zone was similar, with the value of about $3 \%(3.0$ to $3.8 \%)$. The less abundance species seem to be decreased toward the deeper water, while the very rare species tend to increase toward the deeper waters. This phenomenon seems to be consistent with the environmental situation where the survival of the fittest is applied. It is likely that the endemic of fish species in the depth zone of 250 to $1,000 \mathrm{~m}$ around Enggano island dominated by the two main groups, the rare and the very rare species. The very rare species are listed in Table 10, Appendix 1. The most abundance fish species found in the $<500 \mathrm{~m}$ depth zone were Diaphus sp. (Myctophidae) and Ostracoberyx dorgenys (Ostracoberycidae). From a total of 3,103 individual fish found in the catch, these two species reaching to almost $61 \%$, consisted of $44 \%$ Diaphus sp. and $17 \%$ Ostracoberyx dorgenys (Table 3). Flesh analysis of the later species showed that nutrient and steroid content are abundantly found (Suseno et al., 2006). 
Table 2.

The Menhinick Richness index and abundance catagories of deep-sea fish resources in the SE part of Enggano

\begin{tabular}{lcccccc}
\hline \multicolumn{1}{c}{ Items/Depth } & \multicolumn{2}{c}{$<00 \mathrm{~m}$} & \multicolumn{2}{c}{$\mathbf{5 0 0 - 7 5 0 \mathrm { m }}$} & \multicolumn{2}{c}{$\mathbf{7 5 1 - 1 , 0 0 0 \mathrm { m }}$} \\
\hline Richness index (R) & \multicolumn{3}{c}{0.93} & \multicolumn{2}{c}{$1.68(+80.6 \%)$} & $\mathrm{N}(+83.9 \%)$ \\
No. of species & $\mathrm{N}$ & & $\%$ & $\mathrm{~N}$ & $\%$ & $\%$ \\
Most abundance & 2 & 3.8 & 2 & 3.0 & 3 & 3.5 \\
Abundance & 11 & 21.2 & 5 & 7.5 & 19 & 22.4 \\
Less abundance & 18 & 34.6 & 17 & 25.4 & 11 & 12.9 \\
Rare & 12 & 23.1 & 17 & 25.4 & 17 & 20.0 \\
Very rare & 9 & 17.3 & 26 & 38.8 & 35 & 41.2 \\
\hline Total No. species & $\mathbf{5 2}$ & $\mathbf{1 0 0 . 0}$ & $\mathbf{6 7}$ & 100.0 & $\mathbf{8 5}$ & $\mathbf{1 0 0 . 0}$ \\
\hline
\end{tabular}

Table 3.

Percentage of the main catch composition of the deep sea fish in the SE Enggano area

\begin{tabular}{|c|c|c|c|c|c|}
\hline Depth ranges $(\mathrm{m})$ & $<500$ & $50-750$ & & $751-1,000$ & \\
\hline \multicolumn{6}{|c|}{ Dominant families and species (\% of $\mathrm{N})$} \\
\hline Myctophidae & & Neoscopelidae & & Macrouridae & \\
\hline Diaphus sp.1 & 44 & Neoscopelus macrolepidotus & 53 & Caelorinchus divergens & 13 \\
\hline Ostracoberycidae & & Caproidae & & Melanonidae & \\
\hline \multirow[t]{2}{*}{ Ostracoberyx dorgenys } & 17 & Antigonia sp. & 18 & $\begin{array}{l}\text { Melanonus zugmayeri } \\
\text { Ophidiidae }\end{array}$ & 11 \\
\hline & & & & Lamprogrammus niger & 8 \\
\hline Total $(\%)$ & 61 & & 71 & & 32 \\
\hline Total catch $(\mathrm{N})$ & 3,103 & & 1,586 & & 759 \\
\hline
\end{tabular}

The myctophids species are known as meso pelagic fish that usually found acoustically in the form of schooling. It is likely that the estimated biomass of about 1.3 million tonnes found acoustically in the Banda Sea at the depth between 100 to $300 \mathrm{~m}$ reported by Amin \& Nugroho (1990), was the myctophids. This group of fish is known as lantern fish as most of the lower part along the body almost full with luminous gland photophores. This is not surprising as the fish are mostly inhabited the aphotic zone, a zone with perpetual darkness. Differ with the Diaphus sp., the later fish, Ostracoberyx dorgenys is likely to provide a benthic dwelling species. The other two species dominated the catch in the 500 to $750 \mathrm{~m}$ were Neoscopelus macrolepidotus (Neoscopelidae) and Antigonia sp. (Caproidae). From a total of 1,586 individual fish caught, the percentage of these species reaching to about $71 \%$, comprising of $53 \%$ and $18 \%$ respectively. As the myctophid, the lower part of the neoscopelid fish body is also ornamented with bioluminescence photophores. Looking at the body form of this caproid fish it is likely that the fish provide a benthic dwelling species.
The three fish groups abundantly found in the depth zone of 751 to $1,000 \mathrm{~m}$, were the macrourids, the melanonids and the ophidiids. From a total of 759 fish caught, their percentage was around $32 \%$. The most abundant macrourid species was Caelorinchus divergens reaching to about $13 \%$. The second most abundant species was Melanonus zugmayeri (Melanonidae) with the percentage of around $11 \%$, while the third species was Lamprogrammus niger (Ophidiidae) with the percentage of around $8 \%$.

\section{The Waters of the Western Part of Bengkulu}

Because of the limited trawlable ground, number of trawl haul allocated in this waters was only two hauls in the 500 to $750 \mathrm{~m}$ depth zone and another two hauls in the 751 to 1,000 m depth zone. As in the Enggano area, the Richness index in the 751 to $1,000 \mathrm{~m}$ depth zone was $3.6 \%$ higher than in the 500 to $750 \mathrm{~m}$ depth zone (Table 4). 
Table 4. The Menhinick Richness index and abundance catagories of deep sea fish resources in the western part of Bengkulu

\begin{tabular}{|c|c|c|c|c|c|c|}
\hline Items/Depth & \multicolumn{2}{|c|}{$<500 \mathrm{~m}$} & \multicolumn{2}{|c|}{$500-750 \mathrm{~m}$} & \multicolumn{2}{|c|}{$751-1,000 \mathrm{~m}$} \\
\hline Richness index (R) & & & & & & $\%)$ \\
\hline No. of species & $\mathrm{N}$ & $\%$ & N & $\%$ & $\mathrm{~N}$ & $\%$ \\
\hline Most abundance & - & - & 3 & 6.9 & 3 & 5.4 \\
\hline Abundance & - & - & 8 & 18.6 & 5 & 8.9 \\
\hline Less abundance & - & - & 4 & 9.3 & 9 & 16.1 \\
\hline Rare & - & - & 14 & 32.6 & 19 & 33.9 \\
\hline Very rare & - & - & 14 & 32.6 & 20 & 35.7 \\
\hline Total No. species & - & - & 43 & 100.0 & 56 & 100.0 \\
\hline
\end{tabular}

The number of the most abundance species in each depth zone was three species, while the percentage was about $6.9 \%$ and $5.4 \%$ respectively. The less abundance species, the rare and the very rare species seem to be increased toward the deeper water. Based on this phenomenon it is likelly that the inhabitant of deeper waters around western of Bengkulu consisted of the rare and the very rare species. The very rare species in this waters are listed in Table 11, Appendix 1. The most abundance species in each of the two depth zone in the western part of Bengkulu as represented by the highest percentage was placed by the macrourid Caelorinchus divergens. This benthopelagic species seems either to have wider range of depth distribution or the bottom habitat in this area are similar.
The percentage of this species in the two depth zones was 11 and $19 \%$ respectively. The second dominant species in each depth zone was the neoscopelid, Scopelengys tristis, and the alepochepalid, Rouleina guentheri. The respective percentage of the two species in each depth zone was about 10 and $12 \%$ (Table 5). Beside the macrourid species that having wider depth distribution, others species that are also similar with the macrourid were Neoscopelus macrolepidotus (Neoscopelidae), the slickheads, Rouleina guentheri, and Bajacalifornia erimoensis (Alepocephalidae). As in the Ostracoberyx dorgenys, in the flesh of the later species some nutrients and steroid content are abundantly found (Suseno et al., 2007).

Table 5. Percentage catch composition of the deep sea fish in the Western of Bengkulu

\begin{tabular}{|c|c|c|c|c|}
\hline Depth ranges $(\mathrm{m})$ & $500-750$ & \multicolumn{3}{|c|}{$751-1,000$} \\
\hline \multicolumn{5}{|c|}{ Dominant families and species (\% of $\mathrm{N}$ ) } \\
\hline & Macrouridae & & Macrouridae & \\
\hline & Caelorinchus divergens & 11 & Caelorinchus divergens & 19 \\
\hline & Neoscopelidae & & Alepocephalidae & \\
\hline & Scopelengys tristis & 10 & Rouleina guentheri & 12 \\
\hline & Neoscopelus macrolepidotus & 7 & Bajacalifornia erimoensis & 7 \\
\hline & Total $(\%)$ & 27 & & 38 \\
\hline & Total catch $(\mathrm{N})$ & 171 & & 270 \\
\hline
\end{tabular}




\section{The Waters of the NW Part of Simeuleu}

Species diversity in the $<500 \mathrm{~m}$ depth zone was rather poor compared with diversity in the deeper zone. As reflected by the Richness index which is only 0.93 , the Richness index in the deeper waters was more than twice higher.

The most abundance species in the $<500 \mathrm{~m}$ depth zone was only one species with the percentage of about $5.6 \%$, while most of the species in this depth zone (almost 78\%) were belong to the rare and the very rare species groups. The rare and the very rare species in the deeper zone seem to be dominated the deep sea fish community, with the percentage of more than $50 \%$. The very rare species in this waters are listed in Table 12. Appendix 1. The most abundance and the abundance species in the $<500 \mathrm{~m}$ depth zone was only three species, while in the 500 to $750 \mathrm{~m}$ depth zone was 12 species and in the deeper zone was 14 species (Table 6). This information indicates that the deep sea fish community in the $<500 \mathrm{~m}$ depth zone was dominated by only three species. The most abundance species in the $<500 \mathrm{~m}$ depth zone was only one, Ostracoberyx dorgenys of the family Ostracoberycidae with the percentage number reaching to about $68 \%$. Compare with the Enggano area where this species provides the second most abundance in the same depth zone, while in the other deeper zone of both Enggano and of Bengkulu area, this species was hardly ever found. It is likely that the depth distribution of this species is relatively limited up to the depth of less than $750 \mathrm{~m}$. In the 500 to $750 \mathrm{~m}$ and 750 to $1,000 \mathrm{~m}$ depth zone the percentage of the most abundance species was not as high as the percentage number in the $<500 \mathrm{~m}$ depth zone. This appearence indicated that the habitat of fish community in the deeper zone was slightly difference compare with the shallower depth zone. The five most abundance species found in the 500 to $750 \mathrm{~m}$ depth zone were the spinyfins, Diretmoides pauciradiatus (Diretmidae), the macrourid, Caelorinchus divergens, the alfonsinos, Beryx splendens, the ophidiid, Glyptophidium sp., and the slimeheads, Hoplostethus crassispinus of the family Trachichthyidae.

Table 6. The Menhinick Richness index and abundance catagories of deep sea fish resources in the NW part of Simeuleu

\begin{tabular}{lcccccc}
\hline \multicolumn{1}{c}{ Items/Depth } & \multicolumn{2}{c}{$\mathbf{5 0 0 m}$} & \multicolumn{2}{c}{$\mathbf{5 0 0 - 7 5 0 m}$} & \multicolumn{2}{c}{$\mathbf{7 5 1 - 1 , 0 0 0 m}$} \\
\hline Richness index (R) & \multicolumn{3}{c}{0.93} & \multicolumn{2}{c}{$2.53(+172 \%)$} & \multicolumn{2}{c}{$3.02(+19.4 \%)$} \\
No. of species & $\mathrm{N}$ & $\%$ & $\mathrm{~N}$ & $\%$ & $\mathrm{~N}$ & $\%$ \\
Most abundance & 1 & 5.6 & 5 & 4.3 & 4 & 3.6 \\
Abundance & 2 & 11.1 & 7 & 6.1 & 10 & 9.0 \\
Less abundance & 1 & 5.5 & 45 & 39.1 & 39 & 35.1 \\
Rare & 5 & 27.8 & 25 & 21.7 & 30 & 27.0 \\
Very Rare & 9 & 50.0 & 33 & 28.7 & 28 & $\mathbf{2 5 . 3}$ \\
\hline Total No. species & $\mathbf{1 8}$ & $\mathbf{1 0 0 . 0}$ & $\mathbf{1 1 5}$ & $\mathbf{( 1 0 0 . 0 )}$ & $\mathbf{1 1 1}$ & $\mathbf{( 1 0 0 . 0 )}$ \\
\hline
\end{tabular}

The respective percentage composition of these species were $22 \%$, each of the following three species of about $10 \%$, and the last species of almost $9 \%$. The four most abundance species in the 751 to $1,000 \mathrm{~m}$ depth zone were the ophidiid, Lamprogrammus niger, the macrourid, Caelorinchus divergens, the melanonid or pelagic cod, Melanonus zugmayeri, and the other ophidiid, Glyptophidium sp., with a lower percentage of about 11,10 , almost 7 , and $6 \%$ respectively (Table 7 ).

\section{The Waters of the Western Part off Banda Aceh}

As already mentioned earlier that the Richness index was always increased toward the deeper waters in each of the preceding areas, the similar appearences were also happened to the deep sea fish community in northest part of the waters of western Sumatera. 
Table 7. Percentage catch composition of the deep sea fish in the NW part of Simeuleu

\begin{tabular}{|c|c|c|c|c|c|}
\hline Depth ranges $(\mathrm{m})$ & $<500$ & $500-750$ & & $751-1,000$ & \\
\hline \multicolumn{6}{|c|}{ Dominant families and species (\% of $\mathrm{N}$ ) } \\
\hline Ostracoberycidae & & Diretmidae & & Ophidiidae & \\
\hline \multirow[t]{8}{*}{ Ostracoberyx dorgenys } & 68 & Diretmoides pauciradiatus & 22 & Lamprogrammus niger & 11 \\
\hline & & Macrouridae & & Glyptophidium sp. & 6 \\
\hline & & Caelorinchus divergens & 10 & Macrouridae & \\
\hline & & Berycidae & & Caelorinchus divergens & 10 \\
\hline & & Beryx splendens & 10 & Melanonidae & \\
\hline & & Ophidiidae & & Melanonus zugmayeri & 7 \\
\hline & & Glyptophidium sp. & 10 & & \\
\hline & & Trachichthyidae & & & \\
\hline Total (\%) & 68 & 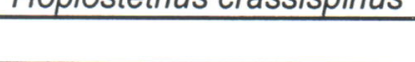 & 61 & & 34 \\
\hline Total catch $(\mathrm{N})$ & 376 & & 2,071 & & 1,348 \\
\hline
\end{tabular}

Table 8.

The Menhinick Richness index and abundance catagories of deep sea fish resources in the Western part of Banda Aceh

\begin{tabular}{|c|c|c|c|c|c|c|}
\hline Items/Depth & \multicolumn{2}{|c|}{$<500 \mathrm{~m}$} & \multicolumn{2}{|c|}{$500-750 \mathrm{~m}$} & \multicolumn{2}{|c|}{$751-1,000 \mathrm{~m}$} \\
\hline Richness index (R) & \multicolumn{2}{|c|}{0.71} & \multicolumn{2}{|c|}{$1.01(+42.3 \%)$} & \multicolumn{2}{|c|}{$2.08(+105.9 \%)$} \\
\hline No. of species & $\mathrm{N}$ & $\%$ & $\mathrm{~N}$ & $\%$ & $\mathrm{~N}$ & $\%$ \\
\hline Most abundance & 1 & 2.9 & 3 & 5.0 & 2 & 3.2 \\
\hline Abundance & 2 & 5.9 & 4 & 6.7 & 5 & 7.9 \\
\hline Less abundance & 11 & 32.4 & 15 & 25.0 & 16 & 25.4 \\
\hline Rare & 9 & 26.5 & 17 & 28.3 & 16 & 25.4 \\
\hline Very Rare & 11 & 32.4 & 21 & 35.0 & 24 & 38.1 \\
\hline Total No. species & 34 & 100.0 & 60 & 100.0 & 63 & 100.0 \\
\hline
\end{tabular}

The most abundance species in each of the three depth zone was one species, three species and two species respectively, while the abundance category was two, four and five species. As already happened in the Simeuleu area, moving to the northern part, it is found that the number of rare and the very rare species in the deeper zone seem to be high. The very rare species in this waters are listed in Table 13, Appendix 1. The percentage of the combined number of rare and very rare species in the $<500 \mathrm{~m}$ depth reaching to almost $60 \%$, and this percentage is increasing toward the deeper zone reaching to about 63.3 and $63.5 \%$ respectively. It is likely that this increasing percentage trend was highly contributed by the very rare species. As can be seen in the table, their respective percentage contribution in each of the three depth zone are 32, 35, and $38 \%$ (Table 9 ).
The most abundance species in the $<500 \mathrm{~m}$ depth zone in this waters was occupied by the mycthopid, Diaphus sp.1. Approximately $92 \%$ of the total number of individual fish in this depth zone was contributed by this species alone. The first of the most abundance species in the 500 to $750 \mathrm{~m}$ depth zone was placed by Ostracoberyx dorgenys, followed by the spinyfins, Diretmoides pauciradiatus and the slimeheads, Hoplostethus rubellopterus. Like in the Simeuleu area, where the spinyfins, Diretmoides pauciradiatus provides the most abundance species in the 500 to $750 \mathrm{~m}$ depth zone, in the western part of Banda Aceh this species respresented the most abundance species in the 751 to $1,000 \mathrm{~m}$ depth zone. Based on this appearence, it is likely that the spinyfins provide the major inhabitant of the deeper waters of the Eastern Indian Ocean. 
The Most Abundance and the Very Rare ..... in the Western Sumatera, Eastern Indian Ocean (Badrudin, et al.)

Table 9. Percentage catch composition of the deep sea fish in the Western part of Banda Aceh

\begin{tabular}{|c|c|c|c|c|c|}
\hline Depth ranges $(\mathrm{m})$ & $<500$ & $500-750$ & & $751-1,000$ & \\
\hline \multicolumn{6}{|c|}{ Dominant families and species ( $\%$ of $\mathrm{N}$ ) } \\
\hline Myctophidae & & Ostracoberycidae & & Diretmidae & \\
\hline \multirow[t]{5}{*}{ Diaphus sp. 1} & 92 & Ostracoberyx dorgenys & 43 & Diretmoides pauciradiatus & 47 \\
\hline & & Diretmidae & & Nettastomatidae & \\
\hline & & Diretmoides pauciradiatus & 27 & Nettastoma solitarium & 14 \\
\hline & & Trachichthyidae & & & \\
\hline & & Hoplostethus rubellopterus & 14 & & \\
\hline Total (\%) & 92 & & 84 & & 61 \\
\hline Total catch $(\mathrm{N})$ & 2,281 & & 3,558 & & 920 \\
\hline
\end{tabular}

Based on the composition data started from the SE of Enggano, western of Bengkulu, NW of Simeuleu and western of Banda Aceh it is likely that there are some differences in the deep-sea fish community between the southern and the northern waters of the imaginary line of the equator. These differences are probably related to the movement pattern of the water current occurring in the deep sea floor which are likely affect the bottom substrate and ultimately affect the fish community inhabited this area. This phenomenon is likely similar with the imaginary Wallace line, a well known biogeographical break that run through the Makassar strait, in separating the differences of the terrestrial fauna between the western and the eastern form as happened to the genetic diversity in wild stock of the giant freshwater prawn, Macrobrachium rossenbergii (Mather $\&$ de Bruyn, 2003).

\section{CONCLUSIONS}

Within the depth range of 250 to $1,000 \mathrm{~m}$ in the western Sumatera waters, the number of species seems to be increased toward the deeper waters. These were reflected by the Menhinick Richness Indices, where the indices were increasing toward the deeper waters. It was also found that the endemic fish community during the survey period dominated by the two main groups, the rare and the very rare species. The six most abundance species in term of numbers of individual fish were the lantern fish myctophids, Diaphus sp.1, the rat tails macrourid, Caelorinchus divergens, the neoscopelids, Neoscopelus macrolepidotus, the spinyfins, Diretmoides pauciradiatus, the alepocephalid, Bajacalifornia erimorensis, and the trachichthyds Hoplostethus crassispinus.

Based on the catch composition data in each area from SE of Enggano to the western part of Banda Aceh, it is likely that there are some differences in the deep sea fish communities between the southern and the northern waters of the imaginary line of the equator. These differences are probably related to the movement pattern of the water current occurring in the deep sea floor which are likely affected the bottom substrate and ultimately affected the fish community inhabited this area.

\section{Acknowledgements:}

This paper is part of 'Indonesian-Japan joint program on deep sea fisheries resources' in 2005.

\section{REFERENCES}

Amin, E. M. \& D. Nugroho. 1990. Acoustic survey pelagic fish resources in the Banda Sea during August 1984 and February-March 1985. Netherlands Journal of Sea Research. 25 (4): 621-625.

Anonymous. 2006. The Japan-Indonesia deep-sea fishery resources joint exploration project. Final Report. Overseas Fishery Cooperation Foundation. Japan-Agency for Marine and Fisheries Research. Ministry of Marine Affairs and Fisheries. Indonesia. $154 \mathrm{p}$.

Badrudin, Wudianto, N. N. Wiadnyana, \& S. Nurhakim. 2006. Deep sea fish resources diversity and potential in the waters of western Sumatera of the Eastern Indian Ocean. Indonesian Fish. Res. Journ. AMFR. Vol.12 No.2 (2006): 113-127.

Ludwig, J. A. \& J. F. Reynolds. 1988. Statistical Ecology. A Primer on Methods and Computing. John Wiley \& Sons. New York. $337 \mathrm{p}$. 
Marshall, N. B. 1979. Development of deep sea biology. Blandford Press. Poole. Dorset. UK. 565 p.

Mather, P. B. \& M. De Bruyn. 2003. Genetic diversity in wild stock of the giant freshwater prawn (Macrobrachium rossenbergii): Implications for aquaculture and conservation. NAGA World Fish Center Quarterly.Vol.26 No.4 Oct-Dec 2003: 4-7.

Nakabo, T. 2002. Fishes of Japan with pectorial keys to the species. Tokai University Press. Book I: $866 \mathrm{p}$. Book II 867-1748.
Nybakken, J. W. 1986. Marine biology: An ecological approach (In Indonesian). Translators: M. Eidman, Koesoebiono, Dietrich, Hutomo, \& Sukardjo). PT. Gramedia. Jakarta. $459 \mathrm{p}$.

Sugiarto, A. \& S. Birowo. 1975 (Eds). Atlas oseanologi Indonesia. Lembaga Oseanologi Nasional. Lembaga IImu Pengetahuan Indonesia (In Indonesian). 79 p.

Sverdrup, H. U., M. W. Johnson, \& R. H.Fleming. 1946. The Oceans. Their physics, chemistry, and general biology. Prentice-Hall. Inc. New York. 1087 p. 
Appendix 1.

Table 10. The very rare species in the SE waters of Enggano

\begin{tabular}{|c|c|c|}
\hline$<500 \mathrm{~m}$ & $500-750 \mathrm{~m}$ & $751-1,000 \mathrm{~m}$ \\
\hline Squalidae & Mitsukurinidae & Mitsukurinidae \\
\hline Squalus sp.1 & Mitsukurina owstoni & Mitsukurina owstoni \\
\hline Squatinidae & Scyliorhinidae & Scyliorhinidae \\
\hline Squatina tergocellatoides & Apristurus sp. 1 & Apristurus sp.1 \\
\hline Plesiobatididae & Halosauridae & Centrophoridae \\
\hline Plesiobatis daviesi & Aldrovandia affinis & Centrophorus sp. 2 \\
\hline Nemichthyidae & Congridae & Plesiobatididae \\
\hline Nemichthys sp. & Congridae sp. 1 & Plesiobatis daviesi \\
\hline Sternoptychidae & Nemichthyidae & Synaphobranchidae \\
\hline Polyipnus sp. & Nemichthys scolopaceus & Meadia abyssalis \\
\hline Neoscopelidae & Serrivomeridae & Nemichthyidae \\
\hline Neoscopelus macrolepidotus & Serrivomer sector & Avocettina sp. \\
\hline Grammicolepididae & Alepocephalidae & Microstomatidae \\
\hline Grammicolepis sp.1 & Rouleina guentheri & Nausenia ardesiaca \\
\hline Xiphiidae & Sternoptychidae & Alepocephalidae \\
\hline Xiphias gladius & Argyropelecus affinis & Alepocephalus sp.2 \\
\hline Bothidae & Sternoptychidae sp.1 & Narcetes sp. \\
\hline \multirow[t]{28}{*}{ Chascanopsetta sp. } & Stomiidae & Alepocephalidae sp.1 \\
\hline & Stomias sp. & Gonostomatidae \\
\hline & Melanostomiidae & Sigmops elongatum \\
\hline & Photonectes margarita & Gonostomatidae sp.1 \\
\hline & Melanostomias sp. & Sternoptychidae \\
\hline & Ateleopodidae & Argyropelecus hemigymnus \\
\hline & Ateleopus sp. & Argyropelecus sladeni \\
\hline & Melanonidae & Chauliodontidae \\
\hline & Melanonus zugmayeri & Chauliodus sloani \\
\hline & Macrouridae & Asteronesthidae \\
\hline & Caelorinchus longissimus & Heterophotus ophistoma \\
\hline & Caelorinchus kamoharai & Asteronesthidae sp. \\
\hline & Ophidiidae & Melanostomiidae \\
\hline & Neobythites sp.1 & Photonectes margarita \\
\hline & Ophidiidae sp.1 & Paralepididae \\
\hline & Lophiidae & Paralepididae sp. \\
\hline & Lophiodes sp. & Evermannellidae \\
\hline & Diceratiidae & Coccorella sp. \\
\hline & Diceratiidae sp. & Myctophidae \\
\hline & Trachichthyidae & Lampadena sp.1 \\
\hline & Hoplostethus rubellopterus & Lampadena sp. 2 \\
\hline & Hoplostethus crassispinus & Myctophidae sp.2 \\
\hline & Grammicolepididae & Myctophidae sp.3 \\
\hline & Grammicolepis sp.1 & Macrouridae \\
\hline & Scorpaenidae & Ventrifossa sp. 2 \\
\hline & Ectreposebastes imus & Lophiidae \\
\hline & Gempylidae & Lophiodes sp. \\
\hline & Rexea promentheoides & Lophiidae sp. \\
\hline
\end{tabular}


Ind.Fish Res.J. Vol.13 No.1 Juni-2007: 17-30

Table $10 . \quad$ Continue

\begin{tabular}{ll}
\multicolumn{1}{c}{$\mathbf{5 0 0 - 7 5 0 ~} \mathbf{~ m}$} & \multicolumn{1}{c}{$\mathbf{7 5 1 - 1 , 0 0 0 ~} \mathbf{m}$} \\
\hline Trichiuridae & Oneirodidae \\
& Oneirodes sp. 1 \\
& Himantolophidae \\
& Himantolophus sp. \\
& Melamphaidae \\
& Melamphaes lugubris \\
& Melamphaidae sp. \\
& Caproidae \\
& Caproidae sp. \\
& Scorpaenidae \\
& Ectreposebastes imus \\
& Epigonidae \\
& Epigonus denticulatus \\
& Centrolophidae \\
& Hyperoglyphe japonica \\
& Chiasmodontidae \\
& Chiasmodon niger
\end{tabular}


Table 11. The very rare species in the Western of Bengkulu

\begin{tabular}{|c|c|}
\hline$<500 \mathrm{~m}$ & $500-750 \mathrm{~m}$ \\
\hline Synaphobranchidae & Scyliorhinidae \\
\hline Synaphobranchus kaupii & Apristurus sp.1 \\
\hline Synaphobranchus sp. & Halosauridae \\
\hline Gonostomatidae & Aldrovandia affinis \\
\hline Gonostomatidae sp.1 & Congridae \\
\hline Sternoptychidae & Congridae sp.1 \\
\hline Argyropelecus affinis & Congridae sp.2 \\
\hline Asteronesthidae & Muraenesocidae \\
\hline Asteronesthidae sp. & Oxyconger leptognathus \\
\hline Photonectes sp. & Derichthyidae \\
\hline Melanostomias sp. & Nessorhamphus ingolfianus \\
\hline Notosudidae & Nemichthyidae \\
\hline Scopelosaurus smithii & Nemichthys scolopaceus \\
\hline Myctophidae & Sternoptychidae \\
\hline Bolinichthys sp. & Argyropelecus affinis \\
\hline Diaphus sp.1 & Sternoptyx sp. \\
\hline Macrouridae & Asteronesthidae \\
\hline Nezumia sp. 1 & Photonectes albipennis \\
\hline Ophidiidae & Melanostomias sp. \\
\hline Ophidiidae sp.2 & Paralepididae \\
\hline Oneirodidae & Lestidium atlanticum \\
\hline Oneirodes sp.1 & Lestidium $\mathrm{sp}$ \\
\hline \multirow[t]{15}{*}{ Leptocephalus } & Myctophidae \\
\hline & Diogenichthys sp. \\
\hline & Macrouridae \\
\hline & Caelorinchus sp.1 \\
\hline & Ventrifossa sp.2 \\
\hline & Ophidiidae \\
\hline & Ophidiidae sp.1 \\
\hline & Lophiidae \\
\hline & Lophiodes sp. \\
\hline & Diceratiidae \\
\hline & Diceratidae sp. \\
\hline & Diretmidae \\
\hline & Diretmoides sp. \\
\hline & Scombrolabracidae \\
\hline & Scombrolabrax heterolepis \\
\hline
\end{tabular}


Table 12. The very rare species around Simeuleu Island

\begin{tabular}{|c|c|c|}
\hline$<500 \mathrm{~m}$ & $500-750 \mathrm{~m}$ & $751-1,000 \mathrm{~m}$ \\
\hline Halosauridae & Centrophoridae & Rhinochimaeridae \\
\hline Aldrovandia affinis & Centrophorus sp & Rhinochimaera africana \\
\hline Serrivomeridae & Plesiobatididae & Rhinochimaera pasifica \\
\hline Serrivomer sector & Plesiobatis sp. & Synaphobranchidae \\
\hline Chlorophthalmidae & Halosauridae & llyophis brunneus \\
\hline Chlorophthalmus acutifrons & Aldrovandia affinis & Nemichthyidae \\
\hline Myctophidae & Congridae & Nemichthyidae sp. \\
\hline Myctophidae sp.1 & Congridae sp.2 & Alepocephalidae \\
\hline Oneirodidae & Derichthyidae & Alepocephalidae sp.2 \\
\hline Chaenophryne draco & Nessorhamphus ingolfianus & Gonostomatidae \\
\hline Diretmidae & Alepocephalidae & Cyclothone sp. \\
\hline Diretmoides pauciradiatus & Alepocephalus sp.1 & Sigmops gracile \\
\hline Zeidae & Leptoderma retropinnum & Sigmops sp. \\
\hline Cyttomimus affinis & Asteronesthidae & Asteronesthidae \\
\hline Cyttopsis rosea & Borostomias sp. & Astronesthes indopasifica \\
\hline Gempylidae & Melanostomiidae & Malacosteidae \\
\hline \multirow[t]{35}{*}{ Neoepinnula orientalis } & Eustomias sp. & Aristomias pol $\square$ dactylus \\
\hline & Ipnopidae & Notosudidae \\
\hline & Bathypterois guentheri & Scopelosaurus mauli \\
\hline & Notosudidae & Paralepididae \\
\hline & Scopelosaurus mauli & Lestrolepis intermedia \\
\hline & Myctophidae & Paralepididae sp. \\
\hline & Benthosema sp. & Myctophidae \\
\hline & Moridae & Myctophum spinosum \\
\hline & Gadella sp. & Myctophum sp. \\
\hline & Bregmacerotidae & Myctophidae sp.2 \\
\hline & Bregmaceros sp. & Macrouridae \\
\hline & Macrouridae & Caelorinchus smithi \\
\hline & Batnygadus sp. & Ophidiidae \\
\hline & Ophidiidae & Chaunacidae \\
\hline & Glyptophidium sp. & Chaunax sp.1 \\
\hline & Neobythites sp.1 & Oneirodidae \\
\hline & Diceratiidae & Bertella sp. \\
\hline & Diceratiidae sp. & Rondeletiidae \\
\hline & Melamphaidae & Rondeletia loricata \\
\hline & Melamphaes longivelis & Barbourisiidae \\
\hline & Scopelogadus mizolepis & Barbourisia rufa \\
\hline & Melamphaidae sp. & Berycidae \\
\hline & Hispidoberycidae & Beryx splendens \\
\hline & Hispidoberyx ambagiosus & Scorpaenidae \\
\hline & Anoplogastridae & Ectreposebastes imus \\
\hline & Anoplogaster comuta & Peristediidae \\
\hline & Scorpaenidae & Satyrichthys amiscus \\
\hline & Setarches longimanus & Carangidae \\
\hline & Triglidae & Carangoides sp. \\
\hline & Pterygotrigla sp. & Gempylidae \\
\hline & Ostracoberycidae & Displospinus multistriatus \\
\hline & Ostracoberyx dorgenys & Unidentified fish \\
\hline & Bathyclupeidae & \\
\hline & Bathyclupea argentea & \\
\hline & Chiasmodontidae & \\
\hline
\end{tabular}


The Most Abundance and the Very Rare ..... in the Western Sumatera, Eastern Indian Ocean (Badrudin, et al.)

Table 12. Continue

\begin{tabular}{ll}
\hline$<500 \mathrm{~m}$ & \multicolumn{1}{c}{$\mathbf{5 0 0 - 7 5 0 \mathrm { m }}$} \\
\hline & Psedoscopelus sagamianus \\
& Chiasmodontidae sp. \\
& Scombrolabracidae \\
& Scombrolabrax heterolepis \\
& Gempylidae \\
& Lepidocybium flavobrunneum \\
& Promethichthys prometheus \\
& Triacanthodidae \\
& Atrophacanthus japonicus \\
\hline
\end{tabular}


Table 13. The very rare species in the Western part of Banda Aceh

\begin{tabular}{|c|c|c|}
\hline$<500 \mathrm{~m}$ & $500-750 \mathrm{~m}$ & $751-1,000 \mathrm{~m}$ \\
\hline Plesiobatididae & Scyliorhinidae & Rhinochimaeridae \\
\hline Plesiobatis sp. & Scyliorhinus sp. & Rhinochimaera africana \\
\hline Gonostomatidae & Hexanclidae & Alopiidae \\
\hline Diplophos taenia & Heptranchias perlo & Alopias superciliosus \\
\hline Sternoptychidae & Centrophoridae & Notacanthidae \\
\hline Sternoptychidae sp.1 & Centrophorus sp. & Notacanthus abbotti \\
\hline Paralepididae & Squalidae & Muraenesocidae \\
\hline Lestidium atlanticum & Squalus sp.1 & Muraenesox sp. \\
\hline Neoscopelidae & Plesiobatididae & Alepocephalidae \\
\hline Neoscopelus macrolepidotus & Plesiobatis sp. & Rouleina guentheri \\
\hline Moridae & Hexatrygonidae & Alepocephalidae sp.1 \\
\hline Gadella jordani & Hexatrygon longirostra & Gonostomatidae \\
\hline Berycidae & Congridae & Sigmops elongatum \\
\hline Beryx splendens & Congridae sp.1 & Gonostomatidae sp.1 \\
\hline Grammicolepididae & Nemichthyidae & Stomiidae \\
\hline Grammicolepis sp.1 & Avocettina sp. & Stomias affinis \\
\hline Serranidae & Alepocephalidae & Malacosteidae \\
\hline Chelidoperca sp. & Talismania sp. & Malacosteus niger \\
\hline Trichiuridae & Sternoptychidae & Ipnopidae \\
\hline Benthodesmus tenuis & Argyropelecus sp.2 & Bathypterois atricolor \\
\hline Triacanthodidae & Sternoptyx sp. & Bathypterois guentheri \\
\hline \multirow[t]{18}{*}{ Atrophacanthus japonicus } & Sternoptychidae sp.1 & Myctophidae \\
\hline & Asteronesthidae & Lampadena sp.1 \\
\hline & Borostomias pacificus & Myctophidae sp.2 \\
\hline & Ophidiidae & Macrouridae \\
\hline & Dicrolene tristis & Bathygadus sp. \\
\hline & Glyptophidium sp. & Nezumia sp.1 \\
\hline & Monomitopus sp.1 & Oneirodidae \\
\hline & Neobythites sp.1 & Oneirodes sp.1 \\
\hline & Scorpaenidae & Oneirodidae sp. \\
\hline & Ectreposebastes imus & Peristediidae \\
\hline & Setarches guentheri & Satyrichthys amiscus \\
\hline & Epigonidae & Acropomatidae \\
\hline & Epigonus sp. & Synagrops japonicus \\
\hline & Nomeidae & Gempylidae \\
\hline & Psenes arafurensis & Nesiarchus nasutus \\
\hline & Chiasmodontidae & Triacanthodidae \\
\hline & Psedoscopelus sagamianus & Atrophacanthus japonicus \\
\hline & Leptocephalus & $\begin{array}{l}\text { Triacanthodidae sp. } \\
\text { Leptocephalus }\end{array}$ \\
\hline
\end{tabular}

